\title{
Human Rights in Field Education: Key Challenges and Ways Forward
}

\author{
Julie A. Steen ${ }^{1}$ \\ Published online: 17 February 2021 \\ (c) The Author(s), under exclusive licence to Springer Nature Switzerland AG part of Springer Nature 2021
}

This special issue of the JHRSW focuses on the preparation of social work students for human rights practice with a particular attention toward the integration of human rights into field education. During the past 15 years, social work education has taken many steps toward meeting the goal of human rights infusion in curricula, and our next step is to carry this to student learning in the field. At the present time, CSWE is preparing an update to social work accreditation standards, and this is an opportunity for innovation and growth related to human rights education in the field. As social work educators consider revisions to the standards, it is important to take a moment to document the existing efforts to integrate human rights into field education and consider ways in which these efforts can be improved. The authors of the 12 articles within this special issue do just this and provide social work educators with an examination of key challenges encountered in these efforts and suggestions for moving forward.

\section{History of Human Rights in Social Work Education}

Though social work began as a profession deeply committed to human rights (Steen, 2006), the human rights philosophy and its core concepts were not explicitly discussed in social work venues until the 1990s. In 1994, the General Assembly of the United Nations (UN) issued a resolution that ushered in the UN Decade for Human Rights Education (United Nations General Assembly, 1994). This same year, the UN Centre for Human Rights (1994) published a manual that guided social work educators in the infusion of human rights content in the social work curriculum. Leadership within the social work academy responded, as evidenced by

Julie A. Steen

jsteen@ucf.edu

1 University of Central Florida, Orlando, FL 32816, USA the early works of Ife (2001), Reichert (1998), Witkin (1998), and Wronka (1994). Unfortunately, these early discussions had yet to reach many social work students as the UN Decade for Human Rights Education came to an end (Steen \& Mathieson, 2005). However, the gap in social work education has been substantially reduced in the last 15 years (Gabel \& Mapp, 2020), as the field has benefited from an increasing attention to human rights and a growing foundation of literature to support human rights education.

Progress was made possible by efforts to integrate human rights into the infrastructure that undergirds social work education. The Council on Social Work Education (2008) first issued a mandate to focus on human rights in the 2008 edition of the Educational Policy and Accreditation Standards (EPAS). Student exposure to human rights concepts was facilitated through a new textbook series edited by Gabel (2015). These texts explicitly applied a rights-based perspective in multiple areas of the curriculum, including clinical practice (Berthold, 2015), community practice (Libal \& Harding, 2015), policy (Gabel, 2016), and research (Maschi, 2016). The field also benefited from the launch of the Journal of Human Rights and Social Work, which fueled philosophical explorations, practice applications, and empirical investigations regarding human rights (Gabel \& Mapp, 2016).

\section{Contributions Within this Special Issue}

Despite the important advancements of the past two decades, the articles in this special issue point to the continued work needed to integrate human rights in social work education, specifically in the field component. The authors outline the key challenges that need to be confronted and present pedagogical options for consideration. These explorations fall into three main areas with foci on the implicit curriculum, the explicit curriculum, and ethical conflicts within students' practice in field. 


\section{Implicit Curriculum}

Our first set of articles focuses on the implicit curriculum, which has been defined by CSWE (2015) as "the learning environment" (p. 14). They include in this definition "the values and priorities in the educational environment, including the field setting" (p. 14). Field supervisors and instructors are important partners in conveying values and establishing priorities within the field setting, and thus, are deserving of consideration in this special issue. In recognition of the relevance of these partners, Banks, Tuggle, and Coleman present a comprehensive training model for field supervisors that guides them in the integration of human rights concepts into the students' field experience and the field agency itself. McDermott, Stafford, and Johnson examine field instructors' knowledge and attitudes regarding racial equity as a human rights issue, in addition to field agency practices regarding racial equity. Another aspect of the learning environment is the way in which field education is structured. Smith, Goins, and Savani document the ways in which the current field education structure impacts students economically. They challenge social work educators to reconsider the structure from a human rights lens and work to reduce economic barriers for students seeking to realize their right to an education.

\section{Explicit Curriculum}

Our second set of articles focuses on the explicit curriculum. These articles include an attention to field opportunities for general human rights education and specialized education on population-specific rights. Quzack, Picard, Metz, and Chiarelli-Helminiak describe a comprehensive effort to integrate human rights into the curriculum and field settings of an MSW program. Harris and Boys present a model for teaching human rights concepts in field units set in legal clinics. They provide guidance for developing these field units and explore the benefits of integrating social work and law students in internship settings. In a diverse set of articles, the authors describe field opportunities for teaching human rights concepts to field students serving indigenous communities, justice-involved populations, refugees, and unaccompanied immigrant children. Thompson, Harpring, and Whitegoat present a model program for preparing students to serve indigenous communities. The perspectives of program staff and a community partner shed light on the structure and benefits of this program. Vance and Rivers focus on a field unit that serves justice-involved populations re-entering society. They outline activities, including a re-entry simulation, that are designed to foster empathy and a clinician-advocate mindset. Noyori-Corbett and Moxley recommend four competencies for field units serving refugees and suggest a human rights observatory and a human rights intervention design workshop as methods for building mastery of these competencies. Evans, Crea, and Soto summarize the human rights challenges for interns serving unaccompanied immigrant children and detail the macro-level roles that interns can play to advance the rights of these children.

\section{Key Challenges}

Our third set of articles focuses on the ethical conflicts inherent in social work practice that challenge our profession and our students. The authors describe situations in which it is difficult to identify and/or implement the best option. Witt and Levin's article includes an exploration of ethical conflicts within policy practice. This piece features a student reflection regarding practicum work at advocacy agencies, where determination of the best option involves a complex consideration of rights versus practicality. Nuckolls and Sosa explore the conflict between universalism and relativism in a student reflection on practicum work in Indonesia. They argue that collaborative advocacy is the best method for addressing human rights issues in international placement settings. Bernhardt, Forgetta, and Sualp apply the concept of moral distress to social work practice in health settings, where students may be limited in their ability to ensure the human right to health for the populations they serve. Their article calls for a greater attention to moral distress when preparing field students for practice.

\section{Conclusion}

As a whole, this special issue demonstrates the rich diversity of opportunities to apply new pedagogical models, restructure and strengthen field education, and explore and resolve human rights-related dilemmas within the field setting. Standing on a foundation of past work by early leaders in social work education, these articles point to the ways in which we can move forward into a deeper engagement with the human rights philosophy and better prepare our students for rights-based practice. Our future will of course be one with unexpected challenges, and our present state attests to this, but the social work profession holds great promise. As the profession more strongly embraces the human rights 
philosophy as its guiding moral force, new adaptations and applications based on culture, place, and time will further enrich social work education and practice and move us closer to the fulfillment of the profession's mission.

\section{References}

Berthold, S. M. (2015). Human rights-based approaches to clinical social work. Springer

Council on Social Work Education. (2008). Educational policy and accreditation standards. Available from https://cswe.org/ getattachment/Accreditation/Accreditation-Process/2008-EPAS/ Reaffirmation/2008educationalpolicyandaccreditationstandards(epas)08-24-2012(1).pdf.aspx

Council on Social Work Education. (2015). Educational policy and accreditation standards. Available from https://www.cswe. org/getattachment/Accreditation/Accreditation-Process/2015EPAS/2015EPAS_Web_FINAL.pdf.aspx

Gabel, S. G. (2015). Forward. In S. M. Berthold, Human rights-based approaches to clinical social work (pp. vii-xvii). Springer

Gabel, S. G. (2016). A rights-based approach to social policy analysis. Springer

Gabel, S. G., \& Mapp, S. (2016). Editorial. Journal of Human Rights and Social Work, 1, 1-2
Gabel, S. G., \& Mapp, S. (2020). Teaching human rights and social justice in social work education. Journal of Social Work Education, 56, 428-441

General Assembly resolution 49/184, United Nations Decade for Human Rights Education, A/RES/49/184 (23 December 1994). Available from https://undocs.org/pdf?symbol=en/A/RES/49/184

Ife, J. (2001). Human rights and social work: towards rights-based practice. Cambridge University Press

Libal, K., \& Harding, S. (2015). Human rights-based community practice in the United States. Springer

Maschi, T. (2016). Applying a human rights approach to social work research and evaluation. Springer

Reichert, E. (1998). Women's rights are human rights: platform for action. International Social Work, 41, 371-384

Steen, J. A. (2006). The roots of human rights advocacy and a call to action. Social Work, 51, 101-105

Steen, J. A., \& Mathiesen, S. (2005). Human rights education: is social work behind the curve? Journal of Teaching in Social Work, 25, $143-156$

UN Centre for Human Rights. (1994). Human rights and social work: A manual for schools of social work and the social work profession. Author

Witkin, S. L. (1998). Human rights and social work. Social Work, 43, 197-201

Wronka, J. (1994). Human rights and social policy in the United States: an educational agenda for the $21^{\text {st }}$ century. Journal of Moral Education, 23, 261-272 